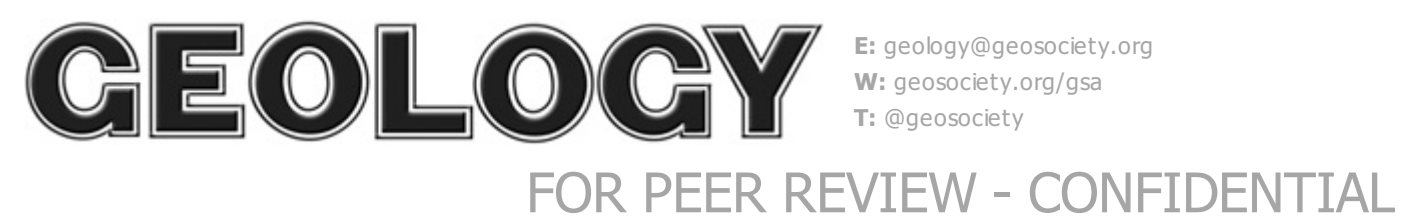

\title{
Early formation and taphonomic significance of kaolinite associated with Burgess Shale fossils
}

Tracking no: G48067R

\section{Authors:}

Ross Anderson (University of Oxford), Nicholas Tosca (University of Oxford), Erin Saupe, Jon Wade (University of Oxford), and Derek Briggs (Yale University)

\section{Abstract:}

The role of minerals in Burgess Shale-type fossilization is controversial, particularly that of the clay mineral kaolinite. Kaolinite may have formed on carcasses or attached to them as they decayed, stabilizing organic matter. Alternatively, kaolinite may have formed during metamorphism, playing no role in the preservation of soft tissues. Evaluating the formation and taphonomic role of kaolinite is difficult, because the mineralogy of Burgess Shale-type fossils is incompletely known. We used in situ selected-area X-Ray diffraction to constrain the mineralogy of fossils from the classic Burgess Shale Formation. Fossils are distinguished from the matrix that surrounds them by the presence of dolomite, kaolinite, and pyrite. Chlorite may be more abundant in the matrix. The preferential survival of kaolinite in association with fossils evidences early diagenetic clay-organic interactions that protected the clay from metamorphic transformation. Kaolinite likely played a crucial role in fossilization, inhibiting the growth of heterotrophic bacteria and aiding polymerization of soft tissue biomolecules. This may result in biases in soft-tissue preservation to areas and times where kaolinite was prevalent. 


\section{Early formation and taphonomic significance of kaolinite associated with}

\section{Burgess Shale fossils}

3 Ross P. Anderson ${ }^{1,2}$, Nicholas J. Tosca ${ }^{3}$, Erin E. Saupe ${ }^{2}$, Jon Wade ${ }^{2}$, Derek E.G. Briggs ${ }^{4}$

$4{ }^{1}$ All Souls College, University of Oxford, Oxford, OX1 4AL, UK

$5 \quad{ }^{2}$ Department of Earth Sciences, University of Oxford, Oxford, OX1 3AN, UK

$6{ }^{3}$ Department of Earth Sciences, University of Cambridge, Cambridge, CB2 3EQ, UK

$7{ }^{4}$ Department of Earth and Planetary Sciences, Yale University, New Haven, Connecticut 06511,

$8 \quad U S A$

9 ABSTRACT

10 The role of minerals in Burgess Shale-type fossilization is controversial, particularly that

11 of the clay mineral kaolinite. Kaolinite may have formed on carcasses or attached to them as they

12 decayed, stabilizing organic matter. Alternatively, kaolinite may have formed during

13 metamorphism, playing no role in the preservation of soft tissues. Evaluating the formation and

14 taphonomic role of kaolinite is difficult, because the mineralogy of Burgess Shale-type fossils is

15 incompletely known. We used in situ selected-area X-Ray diffraction to constrain the mineralogy

16 of fossils from the classic Burgess Shale Formation. Fossils are distinguished from the matrix

17 that surrounds them by the presence of dolomite, kaolinite, and pyrite. Chlorite may be more

18 abundant in the matrix. The preferential survival of kaolinite in association with fossils evidences

19 early diagenetic clay-organic interactions that protected the clay from metamorphic

20 transformation. Kaolinite likely played a crucial role in fossilization, inhibiting the growth of

21 heterotrophic bacteria and aiding polymerization of soft tissue biomolecules. This may result in

22 biases in soft-tissue preservation to areas and times where kaolinite was prevalent.

\section{INTRODUCTION}


Burgess Shale-type (BST) fossil assemblages provide an exceptional wealth of biological

25 information about Cambrian ecosystems, preserving soft tissues and entire soft-bodied

26 organisms. Consequently, much effort has been expended on investigating their taphonomy

27 (Gaines, 2014). BST fossils are preserved primarily as carbonaceous compressions (Butterfield,

28 1990; 1995). However, diagenetic mineralization may have stabilized organic matter or

29 replicated morphology. In the Burgess Shale Formation, for example, a role for apatite and pyrite

30 (known to replicate soft tissues: Briggs 2003) has been documented (Gaines, 2014 and references

31 therein), and clay minerals, specifically the aluminosilicate kaolinite, have been posited to

32 preserve morphological details by precipitating on/attaching to the surface of decaying carcasses

33 (Orr et al., 1998). Resolving the role of minerals in BST fossilization is key to understanding any

34 environmental bias in these fossil assemblages and interpreting the Cambrian fossil record.

The role of clay minerals is particularly controversial due to uncertainties over the timing

36 of their formation. Variation in the abundance of clays on anatomical features of fossils from the

37 Burgess Shale Formation may reflect original tissue chemistry: different clays formed in

38 association with/attached to different decaying tissues, facilitating their preservation (Orr et al.,

39 1998). Alternatively, clays may be a product of greenschist metamorphism that occurred millions

40 of years post fossilization (Powell, 2003) and played no role in the initial conservation of soft

41 tissues. In this case variation may be a product of precipitation from an evolving metamorphic

42 fluid in the space created by the progressive volatilization of individual tissues (Butterfield et al.,

43 2007; Page et al., 2008). However, metamorphism likely resulted in convergence of the

44 fossilized tissues to a kerogen-like composition (e.g., Briggs and Summons, 2014), reducing

45 compositional differences to a level insufficient for differential volatilization. If clays played a 
role in fossilization in the Burgess Shale and other BST localities, then the BST fossil record

47 may be biased to particular environments/times when clay formation was favored.

The primary difficulty in determining when clays formed and evaluating their role in

49 fossilization is our limited knowledge of the precise mineralogy of BST fossils. There is little

50 constraint on mineralogical differences between anatomical features, or between fossils and their

51 matrices. We document for the first time the distribution of minerals across specimens from the

52 Burgess Shale Formation by applying in situ selective-area X-Ray diffraction (XRD) and

53 statistically evaluate mineralogical differences between fossils and matrices. These data

54 complement elemental maps and resolve the formational history of clays. They also constrain the

55 distribution of other taphonomically important minerals, e.g., pyrite. Understanding the role that

56 clays and other minerals played in Burgess Shale fossilization affords critical insight into the

57 taphonomy of this and other BST assemblages, which are crucial to our understanding of early

58 animals.

59 MATERIALS AND METHODS

Elemental and mineralogical data were obtained from Burgess Shale Formation

61 specimens of the stem-polychaete Canadia $(\mathrm{n}=3)$, the stem-arthropods Marrella $(\mathrm{n}=3)$ and

62 Opabinia $(\mathrm{n}=2)$, the stem-priapulid Ottoia $(\mathrm{n}=4)$, and the stem-chordate Pikaia $(\mathrm{n}=3)$. Elemental

63 maps were generated via scanning electron microscopy-energy dispersive X-Ray spectroscopy

64 (SEM-EDS), and mineralogical data were obtained using non-destructive in situ selected-area

65 XRD. The XRD irradiated area was controlled using various configurations of incident beam

66 optics (minimum area is $7 \times 1 \mathrm{~mm}$; for locations of selected-area XRD analyses, see DR). Relative

67 mineral abundances were calculated using the reference intensity ratio method (Snyder and Bish,

68 1989) with Highscore software (referred to as "Highscore data"). This method provides 
69 imprecise identification and quantification of specific clays, so we confirmed the identification

70 of kaolinite - the principal clay argued by Orr et al. (1998) to have played a role in

71 fossilization—by analysis of its $\sim 7 \AA$ peak (Moore and Reynolds, 1997) with Fityk software

72 (referred to as "Fityk data"). Statistical analyses were executed in the R programming language

73 to explore the relationship between selected-area type (i.e., fossil or matrix) and mineralogical

74 composition. For details, see GSA Data Repository (DR), Section 1.

\section{RESULTS}

Selected-area XRD (Figs. 1, 2, DR) revealed that chlorite, muscovite, and quartz are the most abundant minerals in both fossils and their matrices, together with minor amounts of

78 calcite, dolomite, kaolinite, and pyrite.

To assess whether specific minerals are preferentially associated with fossils versus their matrices, we performed mixed effect logistic regression models using a partially Bayesian

81 method (Chung et al., 2013). The relative abundance of each mineral using Highscore data was

82 included as a predictor of selected-area type (i.e., fossil or matrix) in every combination,

83 resulting in 128 possible models including one with no fixed effects (DR Tables S2 and S3).

84 Twenty of the 128 models received non-trivial weight (Akaike's Information Criterion, $\Delta$ AIC <

85 10). Dolomite, kaolinite, and pyrite are significantly more abundant in fossils in all non-trivial

86 models whereas chlorite is more abundant in matrices than fossils. The relative abundances of

87 calcite, muscovite, and quartz were indistinguishable between fossils and their matrices;

88 confidence interval estimates for these minerals were inclusive of zero for most non-trivial

89 models. To compensate for the fact that the predictors are compositional, we ran a suite of

90 models without quartz as a predictor, producing 8 models of non-trivial weight of a possible 64

91 (DR Tables S4 and S5). Results were equivalent to the models inclusive of quartz: dolomite, 
92 kaolinite, and pyrite were significantly more abundant in fossils, whereas chlorite was more

93 abundant in matrices in all non-trivial models. Calcite and muscovite were indistinguishable

94 between fossils and their matrices.

95 We also used partially Bayesian mixed effect logistic models to determine whether the 96 presence/absence of minerals alone could distinguish between fossils and their matrices. We

97 considered only the presence/absence of calcite, dolomite, kaolinite, and pyrite, because chlorite, 98 muscovite, and quartz are present in nearly all (>98\%) selected-area analyses. Of 16 possible

99 models fit using presence/absence derived from Highscore data, six received non-trivial support

100 (DR Tables S6 and S7). The only predictors with confidence intervals exclusive of zero in these

101 models were kaolinite and pyrite, both of which are positively and significantly associated with

102 fossils. The highest-ranking model included only kaolinite and pyrite. Moreover, kaolinite was

103 also found to be positively and significantly associated with fossils when identified using the

104 Fityk data (DR Table S7).

105 SEM-EDS elemental distributions (DR Figs. S1-S15) also distinguish fossils from their

106 matrices and are consistent with the mineralogies identified by selected-area XRD. Aluminum is

107 a major constituent of both kaolinite and muscovite. Features of the digestive system are

108 enriched in aluminum relative to the rest of the fossil. Iron indicative of pyrite often co-varies

109 with carbon, e.g., in the eyes of Opabinia.

\section{DISCUSSION}

111 The data provide statistical support that fossils are distinguished from their matrices by

112 the presence and higher abundances of dolomite, kaolinite and pyrite, and the lower abundance

113 of chlorite. Pyrite is expected to be associated with fossils (Briggs, 2003: DR Section 3.4 for

114 discussion of other minerals). However, the association of kaolinite with fossils provides data 
115 that illuminate its formation (Fig. 3). If kaolinite formed as a retrograde phase, following a

116 metamorphic mineral that precipitated into voids left by the volatilization of soft-tissues

117 (Butterfield et al., 2007; Page et al., 2008), it would likely occur in similar abundance in both

118 fossils and matrices, as this mode of formation involves replacement of illite/muscovite (present

119 in similar abundances in fossils and matrices) in the presence of adequate fluid flow (Nieto et al.,

120 2005). The association of kaolinite with fossils and not matrices, in contrast, supports an early

121 diagenetic origin during carcass decay.

122 Although kaolinite that formed early in diagenesis is unlikely to have survived the

123 metamorphic history of the Burgess Shale Formation (the isochemical nature of most

124 metamorphic reactions in pelitic rocks, and the high aluminum and potassium content of the

125 strata, favor a near quantitative conversion of kaolinite to illite/muscovite and chlorite: Powell,

126 2003), chemical interactions between kaolinite and organic matter provide a viable mechanism

127 for its selective survival on fossils. Bonding of kaolinite to organic matter during early

128 diagenesis could have been facilitated in various ways, and interactions are likely to be localized

129 and dependent on specific functional groups (Theng, 1974). Local decreases in $\mathrm{pH}$ with initial

130 decay (Briggs and Kear, 1993) could have resulted in a net positive charge on the surface of the

131 organic matter, promoting bonding with the negatively charged edge sites of kaolinite (e.g.,

132 Skujinš et al., 1974; Theng, 1974; Yu et al., 2013). Kaolinite edge sites (10-20\% of its surface

133 area: Theng, 1974) behave as Lewis acids; they are likely to have remained negatively charged

134 even at relatively low pH (Sposito, 1984; Brady et al., 1996). Alternatively, cation

135 incorporation/exchange into the organic matter could have increased its isoelectric point (thereby

136 establishing a positive surface charge depending on pore water $\mathrm{pH}$ : Stotzky, 1980), or may have

137 provided a bridge to overcome electrostatic repulsion (Phoenix et al., 2003). Strong binding of 
138 kaolinite to the decaying carcass protected its edge sites from dissolution by aqueous fluids

139 during metamorphism, allowing a small fraction of the mineral to survive. The data do not,

140 however, resolve whether the mineral precipitated directly on carcasses or bonded to them as

141 pre-existing kaolinite. Experimental and theoretical work has shown both silicate formation on

142 organic substrates (Wallace and Schiffbauer, 2016) and the propensity of pre-existing kaolinite

143 to attach to organic substrates including decaying tissues in experiments (Martin et al., 2004;

144 Playter et al., 2017).

145 Given that kaolinite interacted with decaying carcasses, its chemical properties likely

146 played a key role in soft-tissue fossilization (e.g., Butterfield, 1990; 1995). Experimental

147 evidence indicates that kaolinite inhibits the growth of bacterial degraders (likely due to the

148 toxicity of its constiuent $\mathrm{Al}^{3+}$ : DR Section 2), in particular heterotrophic bacteria involved in the

149 decay of marine animals (McMahon et al., 2016). Kaolinite may also stabilize decaying

150 carcasses through its bonds with their organic matter. The bonding properties of kaolinite edge

151 sites (e.g., bond strength and $p \mathrm{Ka}$ ) are unique among clays (Sposito, 1984; Brady et al., 1996)

152 and have been invoked to explain the polymerization (Solomon and Rosser, 1965) and

153 adsorption (Skujinš et al., 1974; Theng, 1974) of organic molecules, as well as the tendency of

154 kaolinite to trigger kerogen maturation upon pyrolysis (Pan et al., 2010). Surface sites located

155 along basal planes could also stabilize pre-existing organic cross-links via the donation of

156 electrons, reducing double bonds and further promoting fossilization (Stimler and Tanzer, 1977).

157 Experiments have shown decay-resistance through tissue polymerization via kaolinite-organic

158 interactions (Wilson and Butterfield, 2014; Naimark et al., 2018).

159 Clay concentrations may have impeded decay more widely by distinct but

160 complementary processes. Globally, sediments hosting BST assemblages are enriched in the 
161 iron-rich clay berthierine, a product of kaolinite exposed to pore-water $\mathrm{Fe}^{2+}$ early in diagenesis

162 (Anderson et al., 2018; Saleh et al., 2019). Consistent with this observation, chlorite (iron-rich:

163 chamosite), the metamorphic product of berthierine, is more abundant in matrices than fossils in

164 almost all our XRD analyses. Bonding to organic matter, which limited transformations of

165 kaolinite including berthierine formation, accounts for this pattern (fig. 3, DR Section 3.2). Like

166 kaolinite, berthierine (probably due to its toxic constituent $\mathrm{Fe}^{2+}$ ) impedes growth of bacteria

167 involved in decay (McMahon et al., 2016; DR Section 2). Thus, preservation may be enhanced

168 by the presence of berthierine transformed from kaolinite in the environs of the carcass, as well

169 as kaolinite attached to it. Soft-tissue preservation in the Burgess Shale and other Cambrian BST

170 assemblages is, therefore, likely to be biased to environs where kaolinite is readily available.

171 Kaolinite forms in regions of high drainage and low $\mathrm{pH}$ today-commonly in the tropics

172 (Wilson, 2013). Consistent with this observation, BST assemblages almost always occur in

173 tropical paleolatitudes (Hendricks et al., 2008).

174 No bias toward the fossilization of particular phylogenetic groups was detected in this

175 work: small sample size precluded assessment of statistical differences in mineralogy between

176 taxa, but kaolinite was present on all specimens including, a stem annelid, a variety of

177 ecdysozoans, and a stem-chordate. Further, evidence suggests kaolinite-organic interactions have

178 played a role in the fossilization of other eukaryotes and even cyanobacteria (Anderson et al.,

179 2020). However, our data do not rule out a bias toward the fossilization of specific animal

180 tissues: more labile tissues, which decay rapidly and drive $\mathrm{pH}$ lower faster, may be more likely to

181 bond with kaolinite (Skujinš et al., 1974; Theng, 1974; Briggs and Kear, 1993; Yu et al., 2013).

182 SEM-EDS data detected enhanced aluminum enrichments associated with labile digestive 
183 organs, indicating that initial kaolinite may have been preferentially associated with these tissues,

184 but sample sizes prevented assessment of these enrichments with XRD data.

185 Despite the evidence of mineral-organic interactions during decay, they were not the only

186 factors controlling Cambrian BST fossilization. Sediment composition (including clay content:

187 Anderson et al., 2018; Saleh et al, 2019), oxidant availability, and the formation of authigenic

188 cements were also important (Gaines, 2014), and their relative contribution presumably varied by

189 setting. The evidence suggests that the mineralogical distinctions between fossils and their

190 associated matrices in the Burgess Shale Formation, specifically the association of kaolinite with

191 fossils, reflect formation in early diagenesis, resolving the controversy over the timing of

192 kaolinite formation and its role in fossilization.

193 ACKNOWLEDGEMENTS

194 D. Erwin, M. Florence, S. Butts, and J. Utrup facilitated access to fossils. We are grateful

195 to S. Kearns for conducting SEM-EDS at the University of Bristol. K. Clayton assisted with

196 XRD analyses. We thank K. Konhauser and J. Schiffbauer for helpful reviews, as well as N.

197 Butterfield, S. Kearns, and two anonymous reviewers for comments on an earlier version. The

198 Leverhulme Trust (PLP-2015-286), a Mid-America Paleontological Society Student Award,

199 NASA (NNA13AA90A and NNX14AP10H), and the Yale Institute for Biospheric Studies and

200 Peabody Museum supported this work.

201 REFERENCES

202 Anderson, R.P., Tosca, N.J., Cinque, G., Frogley, M.D., Lekkas, I., Akey, A., Hughes, G.M.,

203 Bergmann, K.D., Knoll, A.H., and Briggs, D.E.G., 2020, Aluminosilicate haloes preserve 204 complex life approximately 800 million years ago: Interface Focus, v. 10, 20200011. 
Anderson, R.P., Tosca, N.J., Gaines, R.R., Mongiardino Koch, N., and Briggs, D.E.G., 2018, A mineralogical signature of Burgess Shale-type fossilization: Geology, v. 46, p. 347-350, https://doi.org/10.1130/G39941.1.

208

209

210

211

212

213

214

215

216

217

218

219

220

221

222

223

224

225

226

Brady, P.V, Cygan, R.T., and Nagy, K.L., 1996, Molecular controls on kaolinite surface charge: Journal of Colloid and Interface Science, v. 183, p. 356-364 183, 356-364, https://doi.org/10.1006/jcis.1996.0557.

Briggs, D.E.G., 2003, The role of decay and mineralization in the preservation of soft-bodied fossils: Annual Review of Earth and Planetary Sciences, v. 31, p. 275-301, https://doi.org/10.1146/annurev.earth.31.100901.144746.

Briggs, D.E.G., and Kear, A.J., 1993, Decay and preservation of polychaetes: Taphonomic thresholds in soft-bodied organisms: Paleobiology, v. 19, p. 107-135, https://doi.org/10.1017/S0094837300012343.

Briggs, D.E.G., and Summons, R.E., 2014, Ancient biomolecules: Their origins, fossilization, and role in revealing the history of life: BioEssays, v. 36, p. 482-490, https://doi.org/10.1002/bies.201400010.

Butterfield, N.J., 1990, Organic preservation of non-mineralizing organisms and the taphonomy of the Burgess Shale: Paleobiology, v. 16, p. 272-286, https:/doi.org/10.1017/S0094837300009994.

Butterfield, N.J., 1995, Secular distribution of Burgess-Shale-type preservation: Lethaia, v. 28, no. 1, p. 1-13, https://doi.org/10.1111/j.1502-3931.1995.tb01587.x.

Butterfield, N.J., Balthasar, U., and Wilson, L.A., 2007, Fossil diagenesis in the Burgess Shale: Palaeontology, v. 50, p. 537-543, https://doi.org/10.1111/j.1475-4983.2007.00656.x. 
227 Chung Y., Rabe-Hesketh, S., Dorie, V., Gelman, A., Liu, J., 2013, A nondegenerate penalized liklihood estimator for variance parameters in multilevel models: Psychometrika, v. 78, p. 685-709, https://doi.org/10.1007/s11336-013-9329-2.

Gaines, R.R., 2014, Burgess Shale-type preservation and its distribution in space and time: Paleontological Society Papers, v. 20, p. 123-146.

232 Hendricks, J.R., Lieberman, B.S., and Stigall, A.L., 2008, Using GIS to study palaeobiogeographic and macroevolutionary patterns in soft-bodied Cambrian arthropods: Palaeogeography, Palaeoclimatology, Palaeoecology, v. 264, p. 163-175, https:// doi .org /10 .1016/j .palaeo .2008 .04.014.

Martin, D., Briggs, D.E.G., and Parkes, R.J., 2004, Experimental attachment of sediment

McMahon, S., Anderson, R.P., Saupe, E.E., and Briggs, D.E.G., 2016, Experimental evidence that clay inhibits bacterial decomposers: Implications for preservation of organic fossils: Geology, v. 44, p. 867-870, https://doi.org/10.1130/G38454.1.

Moore, D.M., and Reynolds, R.C., 1997, X-Ray Diffraction and the Identification and Analysis of Clay Minerals: Oxford University Press, Oxford, 378pp.

Naimark, E.B., Kalinina, M., Shokurov, A., Markov, A., Zaytseva, L., and Boeva, N., 2018, 248 Mineral composition of host sediments influences the fossilization of soft tissues: Canadian Journal of Earth Sciences, v. 55, p. 1271-1283, https://doi.org/10.1139/cjes2017-0237. 
Nieto, F., Pilar Mata, M., Bauluz, B., Giorgetti, G., Árkai, P., and Peacor, D.R., 2005, Retrograde diagenesis, a widespread process on a regional scale: Clay Minerals, v. 40, p. 93-104, https://doi.org/10.1180/0009855054010158.

Orr, P.J., Briggs, D.E.G., and Kearns, S.L., 1998, Cambrian Burgess Shale animals replicated in clay minerals: Science, v. 281 , p. $1173-1175$, https://doi.org/10.1126/science.281.5380.1173.

Page, A., Gabbott, S.E., Wilby, P.R., and Zalasiewicz, J.A., 2008, Ubiquitous Burgess Shalestyle "clay templates" in low-grade metamorphic mudrocks: Geology, v. 36, p. 855-858, https://doi.org/10.1130/G24991A.1.

Pan, C., Geng, A., Zhong, N, and Liu, J., 2010, Kerogen pyrolysis in the presence and absence of water and minerals: Steranes and triterpenoids: Fuel, v. 89, p. 336-345, https://doi.org/10.1016/j.fuel.2009.06.032.

Phoenix, V.R., Konhauser, K.O., and Ferris, F.G., 2003, Experimental study of iron and silica immobilization by bacteria in mixed Fe-Si systems: Implications for microbial silicification in hotsprings: Canadian Journal of Earth Sciences, v. 40, p. 1669-1678, https://doi.org/10.1139/E03-044.

Playter, T.L., Konhauser, K.O., Hodgson, C.A., Owttrim, G., Mloszewska, A., Sutherland, B., Bekker, A., Zonneveld, J.-P., Pemberton, S.G., and Gingras, M.K., 2017, Microbe-clay interactions as a mechanism for the preservation of organic matter and trace metal biosignatures in black shales: Chemical Geology, v. 459, p. 75-90, https://doi.org/10.1016/j.chemgeo.2017.04.007 
270 Powell, W., 2003, Greenschist-facies metamorphism of the Burgess Shale and its implications 271 for models of fossil formation and preservation: Canadian Journal of Earth Sciences, v. $272 \quad 40$, p. 13-25, https://doi.org/10.1139/e02-103.

273 Saleh, F. Pittet, B., Perrillat, J.-P., Lefebvre, B., 2019, Orbital control on exceptional fossil 274 preservation: Geology, v. 47, p. 103-106, https://doi.org/10.1130/G45598.1.

Skujinš, J., Pukite, A., and McLaren, A.D., 1974, Adsorption and activity of chitinase on kaolinite: Soil Biology and Biochemistry, v. 6, p. 179-182, https://doi.org/10.1016/00380717(74)90024-8.

Snyder, R.L., and Bish, D.L., 1989, Quantitative analysis, in Bish, D.L., and Pose, J.E., eds., Modern Powder Diffraction: Reviews in Mineralogy, v. 20, Mineralogical Society of America, p. 101-144.

Solomon, D.H., and Rosser, M.J., 1965, Reactions catalyzed by minerals. Part 1. Polymerization of styrene: Journal of Applied Polymer Science, v. 9, p. 1261-1271, https://doi.org/10.1002/app/1965.070090407.

Sposito, G., 1984, The surface chemistry of soils: Oxford, Oxford University Press, 234 p.

Stimler, N.P., and Tanzer, M.L., 1977, Location of the intermolecular cross linking sites in collagen in Friedman, M., eds. Protein crosslinking. Advances in Experimental Medicine and Biology, Volume 86: Boston, Springer, p. 675-697.

Stotzky, G., 1980, Surface interactions between clay minerals and microbes, viruses and soluble organics, and the importance of these interactions to the ecology of microbes in soil in Berkeley, R.C.W., Lynch, J.M, Melling, J., Rutter, P.R., Vincent, B., eds. Microbial adhesion to surfaces: Ellis Horwood, Chichester, p. 231-247. 
Theng, B.K.G., 1974, The chemistry of clay-organic reactions: New York, John Wiley and Sons, $343 \mathrm{p}$.

294 Wallace, A.F., and Schiffbauer, J.D., 2016, Model systems as probes of organic-mineral interactions in ancient environments: Geological Society of America Abstracts with Programs, v. 48, https://doi.org/10.1130/abs/2016AM-285087.

Wilson, M.J. 2013 Rock forming minerals, 3C: Clay minerals: London, The Geological Society of London, $724 \mathrm{p}$.

Wilson, L.A., and Butterfield, N.J., 2014, Sediment effects on the preservation of Burgess Shaletype compression fossils: Palaios, v. 29, p. 145-154, https://doi.org/10.2110/palo.2013.075.

Yu, W.H., Li, N., Tong, D.S., Zhou, C.H., Lin, C.X., and Xu, C.Y., 2013, Adsorption of proteins and nucleic acids on clay minerals and their interactions: A review: Applied Clay Science, v. 80-81, p. 443-452, https://doi.org/10.1016/j.clay.2013.06.003.

\section{FIGURE CAPTIONS}

Figure 1: Representative selected-area XRD and SEM-EDS maps of Marrella (USNM 229990).

A: Photograph with selected-areas covering the fossil (numbers refer to XRD analyses: DR Table S1). B-C: SEM-EDS maps showing the distribution of Al, C, Si, and Ca, Fe, P. D:

Representative selected-area XRD (fossil analysis from selected-area 1 in A; Chl=chlorite,

311 Figure 2: Box plots showing mineralogy across specimens recorded by selected-area XRD using 312 Highscore data.

313 Figure 3: Fate of kaolinite through early diagenesis and metamorphism in fossils versus matrices. 
314 Differences in the relative importance of the transformations (thickness of arrows denotes

315 importance) produced the distinct fossil/matrix mineralogy.

316

$317{ }^{1}$ GSA Data Repository item 202Xxxx, Further methodological particulars, antibacterial

318 properties of clays, other minerals with distinct fossil/matrix distributions, summaries of

319 mineralogy by taxon, data tables, statistical summaries, and light/SEM-EDS images of fossil

320 specimens showing XRD selected-areas is available online at

321 www.geosociety.org/pubs/ft20XX.htm, or on request from editing@geosociety.org or

322 Documents Secretary, GSA, P.O. Box 9140, Boulder, CO 80301, USA. 
Calcite

Chlorite

All taxa

$\begin{array}{ll}\mathrm{n}_{\text {specimens }} & =15 \\ \mathrm{n}_{\text {fossil }} & =90 \\ \mathrm{n}_{\text {matrix }} & =57\end{array}$
Canadia

.
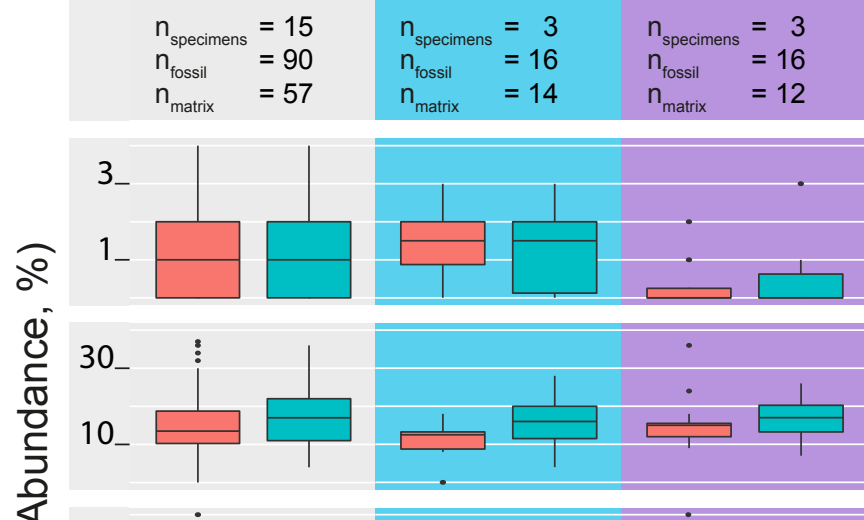

$n_{\text {fossil }}=21$

$\mathrm{n}_{\text {fossil }}=19$

$\mathrm{n}_{\text {matrix }}=6$

$\mathrm{n}_{\text {matrix }}=13$

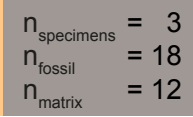

Dolomite

Kaolinite

Muscovite

Pyrite

Quartz

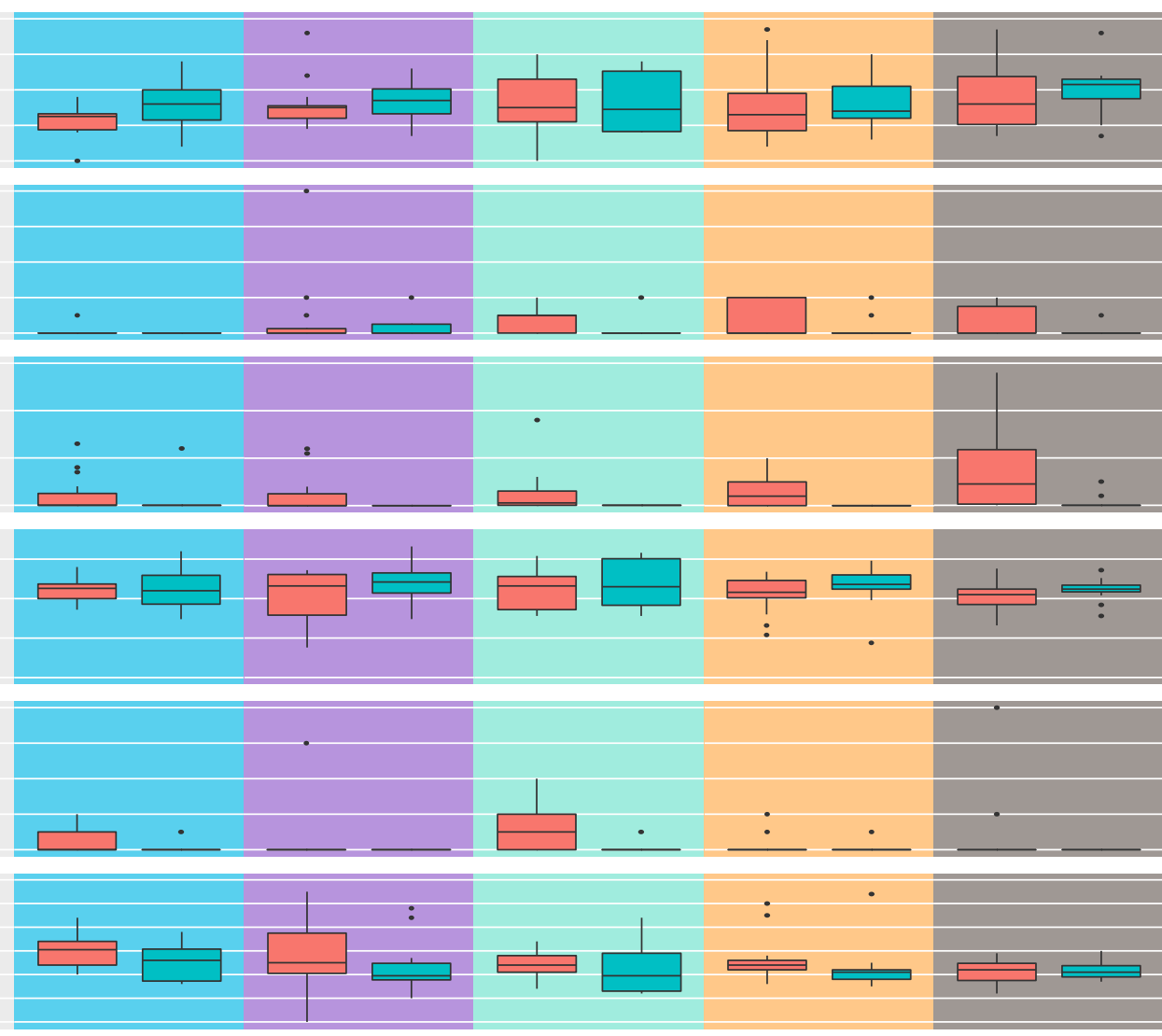

\footnotetext{
fossil analyses matrix analyses
} 


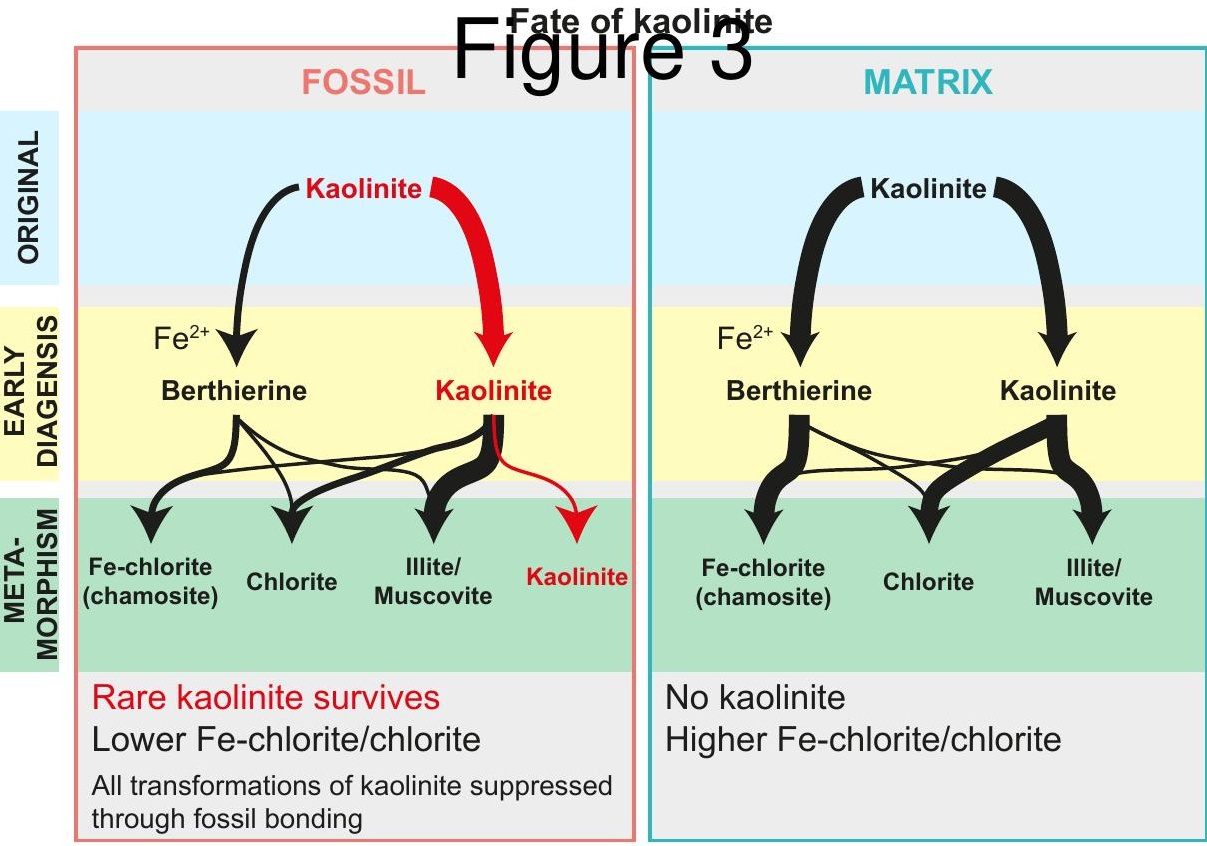

